\title{
THE ROLE AND IMPORTANCE OF TRAINING FOR IMPROVING THE SAFETY AND AWARENESS OF THE TECHNICAL STAFF IN THE MINING PLANT
}

\author{
Dorota Palka ${ }^{1}$
}

\begin{abstract}
Harsh working conditions and the introduction of technologically advanced machines are placing growing demands on the qualifications of mine workers, forcing mine workers to undergo continuous training. This article presents the results of research concerning the evaluation of training and expectations of workers in a mining plant to identify further actions in this area. The results indicate that workers negatively evaluate previous training. Based on advanced expert interviews and panel discussions, the directions and recommendations regarding the necessary changes to training are set out. Employees suggest broadening the subject of occupational health and safety training. Their concerns relate to the operation and maintenance of new machines, telecommunication equipment, mining support, ventilation, and interpersonal communication. The results indicate a growing awareness among employees of the role and importance of training and the acceptance of upgrading skills as an investment in the future.
\end{abstract}

UDC Classification: 622.8; DOI: http://dx.doi.org/10.12955/cbup.v5.1095

Keywords: OHS training, technical awareness, mining, safety

\section{Introduction}

Currently, the Polish coal mining industry employs almost 171 thousand people. This number includes people employed directly in the mines as well as various mining companies. In this industry, the current, and future jobs in many cases depend on the economy of the country and condition of the mining industry. This sector is particularly important for the economy of Upper Silesia, which is a region with a huge mining tradition. Despite changes in the employment structure, the development of other sectors of the economy, and the restructuring of the mining industry, this sector continues to be one of the largest employers in the region. It has a huge impact on the region in terms of shaping the economic picture by employing thousands of residents and being a major source of income for families. At the same time, working in the mining industry, especially underground, is challenging and dangerous. The complex environmental conditions under which underground mining operates and both numerous natural (Brodny \& Tutak, 2016a; 2016b) and technical hazards result in many accidents, including fatalities in the mining industry. Mining and its products, especially gas, are also a significant threat to the external environment (Brodny \& Tutak, 2016a; 2016b). Together these factors coincide with a high accident rate within the industry.

Various types of activities are undertaken to improve this situation and increase the safety of the workers. One example is the widespread use of various types of sensors to monitor the condition of the atmosphere in the mine. In most cases, these sensors form large systems that automatically monitor the level of the hazard in a specific area. Their task is to detect hazards as early as possible and alert workers. In many cases, the parameters registered by these systems are used for forecasting hazardous conditions. More reliable and safer mining machines are also introduced to improve safety (Brodny, 2012). The manufacture of modern mining machinery involves the latest technologies and innovative technical solutions. The aim is to improve both the safety of people operating the machines and the efficiency of the machine (Stecula \& Brodny, 2016; Brodny, Stecula \& Tutak, 2016).

Another step taken by mining companies to improve safety on mining premises is the implementation of occupational safety management systems (Ochman, 2011).

Despite efforts to improve safety at work in mining companies, the mining industry continues to have the highest industrial accident rates. Table 1 presents the number of accidents in the mining industry during 2012-2017, showing the serious, fatal, and overall number of accidents.

An analysis of the data in Table 1 reveals that despite the use of advanced technologies and technical solutions, the number of accidents in mining is high. A deeper analysis of the causes of this situation shows that the employees have a strong impact on the number of accidents. People in harsh environmental conditions with many dangers are the weakest link in the whole system, with an

\footnotetext{
${ }^{1}$ Faculty of Organization and Management, Silesian University of Technology, dorota.palka@ polsl.pl
} 
analysis of the causes of the accidents confirming this theory. In practice, despite the use of modern monitoring systems for the state of the underground environment and the use of modern machines, human errors are the most common cause of all types of accident events (Matuszewski, 2009).

\begin{tabular}{|c|c|c|c|c|}
\hline & Year & Fatal & Serious & All Types \\
\hline & $2017\left(1^{\text {st }}\right.$ of Jan to $1^{\text {st }}$ of Mar $)$ & 3 & 3 & 123 \\
\hline & 2016 & 10 & 5 & 1575 \\
\hline & 2015 & 12 & 7 & 1695 \\
\hline & 2014 & 14 & 7 & 1788 \\
\hline & 2013 & 20 & 22 & 1908 \\
\hline & 2012 & 22 & 11 & 2199 \\
\hline & Total & 81 & 55 & 9288 \\
\hline
\end{tabular}

Thus, action to improve this condition is needed. Such activities should include, in particular, the proper preparation and training of mine workers. Appropriate awareness and commitment of the employee, who has decisive influence on the effectiveness of production and level of occupational safety.

Difficult working conditions, numerous hazards, as well as the variety of technology used in mining require employees of mining companies to improve their knowledge continually. Acquisition of both practical and theoretical knowledge is possible through participation in various types of training.

The aim of this article is to indicate the importance of training for improving the safety and technical awareness of employees.

\section{Data and Methodology}

The study entailed a survey with questionnaires and discussion panels involving coal miners. The objective of the research was to contribute towards improving work safety in the mining industry. The study was carried out with pit crew and surface mining companies and included electricians, drivers, surface mechanics, and employees involved in material processing. The audit questionnaire was open and anonymous, and information sought included age, work experience, and education of the respondents. The study was conducted over five consecutive days with each day involving a different group of employees completing the questionnaire. The survey consisted of two parts that included 15 questions overall. The first part contained five closed questions to verify details of the respondent. The second part contained both open and closed questions (10 each) on assessing the training. The questions were designed to allow employees to express themselves freely on topics of ongoing and future training.

One of the basic questions asked of the employees was to evaluate the organization of their training to date. In another, this time an open question, respondents were asked to provide suggestions for changes in their training necessary to improve their engagement.Results revealed certain areas required detailed discussion. For this purpose, panel discussions were organized and attended by representatives of particular groups of employees. The subject of the discussion covered issues about the role and importance of training. These discussions involved expanded questionnaires. The main purpose of these discussions was to understand the genuine reasons for responses and views of employees and gather proposals for change.

\section{Results and Discussion}

The employees' evaluation of their training regarding its organization are presented in Figure 1 . The results show that most respondents regarded the organization of their current training negatively. Among the answers were the terms 'bad' and 'rather bad', which comprised over $70 \%$ of total responses to this question. 


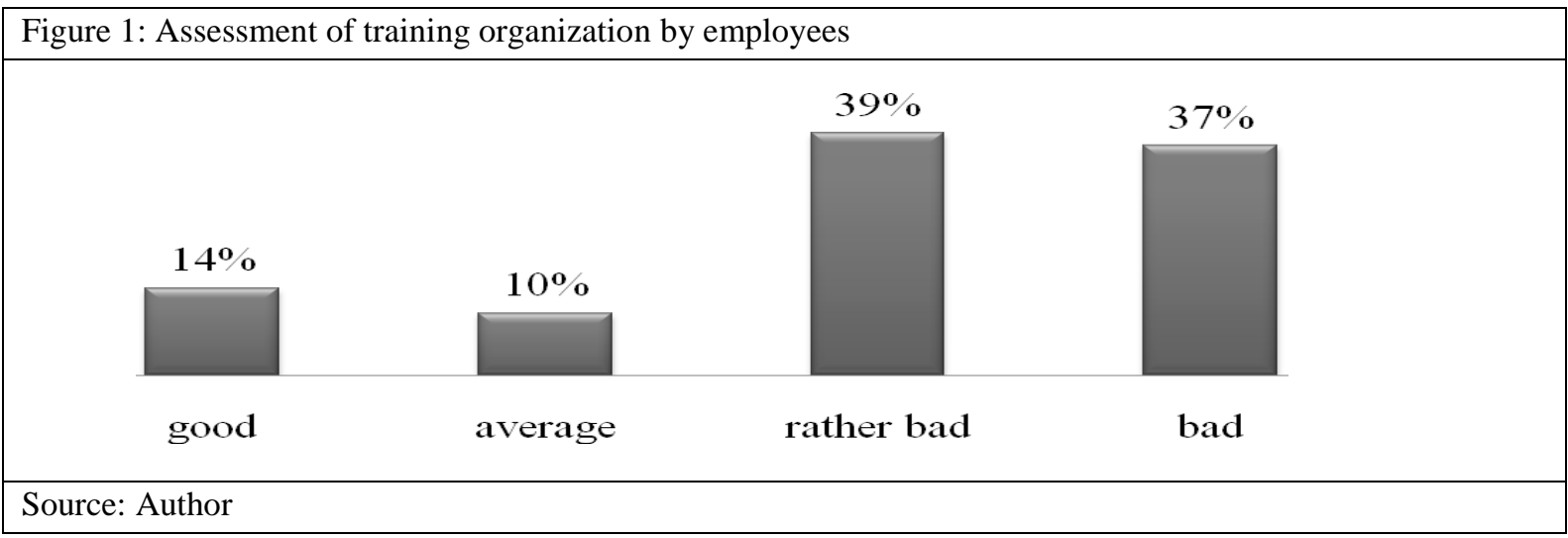

The research results regarding suggestions for changes in employee training to improve their engagement are shown in Figure 2. Almost half of the respondents showed interest in more practical activities. More than 30\% suggested updating the technical knowledge provided during training on the operation of machinery and equipment introduced by the company. The other $20 \%$ recommended trainers use modern methods of transferring knowledge during training. They believed that this would result in greater diversification of training and provide more interest in the topics. The respondents also suggested lengthening the practical part of their training. The theoretical component was assessed negatively in many instances because the workers failed to see the connection between theory and practice.

\begin{tabular}{|c|c|c|}
\hline Figure 2: Employees' suggested changes to improve their engagement in training being offered \\
\hline
\end{tabular}

The discussion panels identified a set of problems viewed by employees regarding their training. The monotony of the lectures and the way the lecturers conveyed the knowledge were two significant problems identified. Employees showed interest in new techniques of knowledge transfer, multimedia presentations, and stimulating teaching aids. Another problem identified was the incompatibility between theory and practice. Employees emphasized significant shortcomings in technical training in relation to modern machinery introduced into the company.

They believed that the development of the company depends on a well-organized training policy of the company. Respondents proposed extending the training program to include technical issues relating to operating new machinery, telecommunications equipment, mining enclosures, ventilation processes, and interpersonal communication. Thus, employees showed their willingness to participate in additional activities, and this is evidence of the growing awareness among employees of the role and importance of training.

\section{Conclusions}

As previously stated, mining is a sector characterized by a high number of accidents due to numerous hazards, difficult working conditions, and above all, the human factor. It is undisputed that the safety of the crew depends largely on the conscious and voluntary commitment of the employees. To 
improve this condition, it is necessary to conduct cyclic training of a crew who may be subject to rotating shifts. New employees, in particular, require proper preparation for such a difficult job. To increase the level of their knowledge, it is therefore necessary to conduct training in terms of both occupational safety and the operation of modern equipment. Proper training improves the efficiency and safety of employees and has a significant impact on the development of the company. Therefore, special emphasis should be given to the proper organization of training and the whole of training policy pursued by the company. The results of questionnaires and discussion panels have shown that employees perceive significant mistakes in the organization of their training. The most important involved monotony and lack of training updates. An important shortcoming is the incompatibility of the presented theory with practical work in the mining industry. Employees have shown interest in modern training methods and in extending the training program. In addition, they have declared their willingness to participate in additional training on technical aspects of equipment. Proposed changes may be the key to resolving a technical barrier that arises together with the dynamic development of technology. This research and its analysis demonstrate the importance of training for the safety and awareness of the employees. It is recommended the outcomes are considered in company training policies. Breaking the technical barrier, raising awareness of the workers, and safety of the crew should have a significant impact on the development of the company. The results of this research contribute towards improving and organizing training not only in mining companies but in other types of industries.

\section{References}

Brodny, J. (2012). Analysis of operation of new construction of the frictional joint with the resistance wedge. Archives of Mining Sciences, 57(1), 209-227.

Brodny, J., Stecuła, K., Tutak, M. (2016). Application of the TPM strategy to analyze the effectiveness of using a set of mining machines. Proceedings of 16th International Multidisciplinary Scientific GeoConferences SGEM 2016, Book 1, Vol. II, Albena Bulgaria, 65-72. DOI: 10.5593/SGEM2016/B12/S03.009.

Brodny, J., Tutak, M. (2016a). Determination of the zone endangered by methane explosion in goaf with caving of operating longwalls. Proceedings of 16th International Multidisciplinary Scientific GeoConferences SGEM 2016, Book 1, Vol. II, Albena Bulgaria, 299-306. DOI: 10.5593/SGEM2016/B12/S03.039.

Brodny, J., Tutak, M. (2016b). The impact of the flow volume flow ventilation to the location of the special hazard spontaneous fire zone in goaf with caving of operating longwalls. Proceedings of 16th International Multidisciplinary Scientific GeoConferences SGEM 2016, Book 1, Vol. II, Albena Bulgaria, 897-904. DOI: 10.5593/SGEM2016/B12/S03.115.

Matuszewski, K. (2009). Przyczyny wypadków przy pracy w górnictwie w aspekcie profilaktyki., Bezpieczeństwo Pracy: nauka i praktyka (2), 22-25.

Ochman, G. (2011). System zarządzania bezpieczeństwem i higieną pracy jako element zintegrowanego systemu zarządzania na przykładzie Kompanii Węglowej S.A., Wybrane problemy inżynierskie (2), 281-286.

Polska Grupa Górnicza. Zintegrowany system zarządzania [online, dostęp: 10.03.17], www.pgg.pl/o-firmie/zsz.

Stecuła, K., Brodny, J. (2016). Application of the OEE model to analyze the availability of the mining armored face conveyor. Proceedings of 16th International Multidisciplinary Scientific GeoConferences SGEM 2016, Book 1, Vol. II, Albena Bulgaria, 57-64. DOI: 10.5593/SGEM2016/B12/S03.008.

Tutak, M., Brodny, J. (2016a). Analysis of gases emitted into the atmosphere during an endogenous fire. Green Extended Scientific Sessions, Proceedings of Conferences in Vienna SGEM 2016, Book 4, Vol3, Vienna Austria, 75-82. DOI: 10.5593/SGEM2016/HB43/S06.011.

Tutak, M., Brodny, J. (2016b). Analysis of methane emission into the atmosphere as a result of mining activity. Green Extended Scientific Sessions, Proceedings of Conferences in Vienna SGEM 2016, Book 4, Vol3, Vienna Austria, 83-90. DOI: 10.5593/SGEM2016/HB43/S06.012.

Wyższy Urząd Górniczy. Statystyki wypadków [online, dostęp: 5.03.17], www.wug.gov.pl/bhp/statystyki_wypadków. 